ISSN: 1679-3013

D.O.I.: 10.5914/to.2011.0050

\title{
SHELL MORPHOMETRY OF THREE SPECIES OF THE GENUS NUCULANA LINK, 1807 (BIVALVIA, PROTOBRANCHIA, NUCULANIDAE) FROM CONTINENTAL SHELF AND SLOPE NORTHEASTERN BRAZIL
}

Recebido em: 19/08/2010

Aceito em: 20/01/2011

Jonata de Arruda FRANCISCO ${ }^{1 *}$

Deusinete de Oliveira TENÓRIO ${ }^{2}$

José Carlos Nascimento de BARROS $^{3}$

Juliana Gabrielle Arcelino da SILVA ${ }^{4}$

Gutembergue Francisco da SILVA ${ }^{4}$

\section{RESUMO}

Este trabalho investigou e comparou os padrões de forma e tamanho das conchas de três espécies do gênero Nuculana Link, 1807, N. acuta (CONRAD, 1831), N. concentrica (SAY, 1824) e N. larranagai Klappenbach \& Scarabino, 1968, coletadas na Plataforma e Talude Continental do Nordeste do Brasil. Um total de 30 valvas de cada espécies foram utilizadas no estudo. Através de estudos baseados em morfometria geométrica foi possível fazer comparações morfológicas usando o método de superposição de marcos anatômicos. A análise de variáveis canônicas mostrou existir diferenças conquiliológicas no tamanho e na forma das espécies, corroborando com a separação inicial dos táxons em $74 \%$ dos casos.

Palavras-chave: Morfometria geométrica, Oceano Atlântico Sul, Bivalves

\section{ABSTRACT}

This study investigated and compared the patterns of shape and size of the shells of three species of the genus Nuculana Link, 1807. Nuculana acuta (Conrad, 1831), N. concentric (Say, 1824) and N. larranagai Klappenbach \& Scarabino, 1968, collected in the continental shelf and slope in northeastern Brazil. A total of 30 valves of each species were used in the study. Through studies based on geometric morphometric was possible morphological comparisons using the method of superposition of anatomic landmarks. The canonical variate analysis showed differences conchologically in size and shape of species, corroborating the initial separation of the taxa in $74 \%$ of cases.

Keywords: Geometric morphometry, South Atlantic Ocean, Bivalves

\section{INTRODUCTION}

The members of the genus Nuculana Link, 1807 (Bivalvia, Protobranchia, Nuculanidae) includes marine bivalve species deposit feeders of soft sediments that are abundant in deep sea (ZARDUS, 2002). The shells are robust, moderately long, anterior umbo, postdorsal margin straight or concave (ALLEN; SANDERS, 1996). They have conservative features and, according to this, a lot of species shows a continuity of shape (MAXWEL, 1988). In Atlantic Ocean it is represented by approximately 50 recent species (ROSENBERG, 2010). Currently, there are seven species reported for Brazilian waters (RIOS, 2009).

The problem of subjectivity in taxonomical analysis (FUIMAN et al., 1999) is that similar species that are associated to a similar habitat complicates its identification

Contato: ${ }^{\mathbf{1}, \mathbf{2}}$ Laboratório de Bentos, Departamento de Oceanografia, Universidade Federal de Pernambuco, Avenida Arquitetura, SN Cidade Universitária, 50670-901, Recife - PE, Brazil.

3,4 Laboratório de Malacologia, Departamento de Pesca e Aquicultura, Universidade Federal Rural de Pernambuco, Avenida Dom Manoel de Medeiros, S/N, Dois Irmãos, 52171-030, Recife, Brazil. 
FRANCISCO, J. de A. et al. Shell morphometry of three species of the genus Nuculana Link, 1807 (Bivalvia, Protobranchia, Nuculanidae) from continental shelf and slope Northeastern Brazil.

(ABSALÃO; ROBERG, 1999). Studies based on morphometrical techniques may help in these cases (FUIMAN et al., 1999; RUGGIERO et al., 2008; ASTÚA, 2009).

Regional morphotypes analysis is fundamental for detection of shape and size differences among the bivalve in question.

This study aimed to identify specific patterns of shape and size on valves of three species of genus Nuculana, N. acuta (CONRAD, 1831), N. concentrica (SAY, 1824) e $N$. larranagai Klappenbach \& Scarabino, 1968, collected from the continental shelf and slope from the Northeast Brazil.

\section{MATERIAL AND METHODS}

The material studied for biometric and morfometry analises was obtained from the followings oceanographic expeditions (Tab. 1):

Table 1 - Origen of the valves samples of the Nuculana species examined with respective localization.

\begin{tabular}{llcrccc}
\hline \multicolumn{1}{c}{ Species } & Expedition & Station & Depth & Latitude & Longitude & Date \\
\hline Nuculana acuta & Geomar & 47 & $43 \mathrm{~m}$ & $0^{\circ} 37^{\prime} \mathrm{N}$ & $47^{\circ} 51^{\prime} \mathrm{W}$ & $9 / \mathrm{VI} / 68$ \\
N. concentrica & Itamaracá & 91 & $1.5 \mathrm{~m}$ & $7^{\circ} 35^{\prime} \mathrm{S}$ & $34^{\circ} 48^{\prime} \mathrm{W}$ & $29 / \mathrm{II} / 69$ \\
N. larranagai & REVIZEE & 08 & $100 \mathrm{~m}$ & $11^{\circ} 58^{\prime} \mathrm{S}$ & $36^{\circ} 49^{\prime} \mathrm{W}$ & $8 / \mathrm{XI} / 00$
\end{tabular}

Abbreviations on table: $\mathrm{m}$ - meters; N-North; S- South; W-West;

The identification of the species is based on comparisons against type material and/or original descriptions and illustrations. Conchological characterization was based on Allen and Hannah (1986), and Maxwell (1988). There were selected 30 valves from each species.

Using a digital camera photos were taken from the external view of the right valves. Scales were included in all images. There were defined four landmarks (Fig. 1) and digitalized with TPSdig 2.

Shapes of the valves were compared using canonical variates analysis (CVA). The analysis of CVA was calculated using the program MorphoJ 1.00. The scores obtained through canonical variate analysis (CVA) were correlated with the scores of centroid size, obtained with Morpho], to exhibit the significance of size in the shape of valves. Graphics were made using Statistica 7.

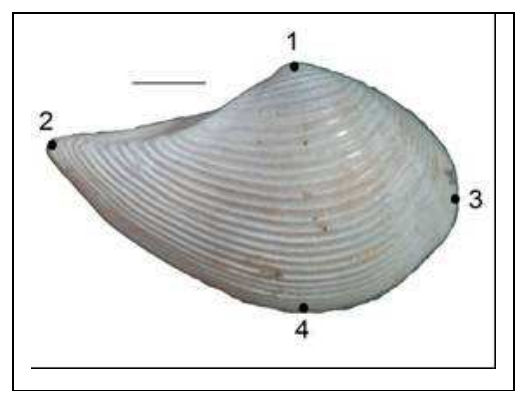

Figure 1 - Right valve of Nuculana with Landmarks and diagram used in this analysis. Landmarks: 1.umbo; 2. Rostrum; 3. anterior margin; 4. ventral margin. Scale: $1 \mathrm{~mm}$

Abbreviations utilized through the text: CV1-first canonical variate; CV2- second canonical variate. Lt - Length of valve; Wt - width of valve; $\mathrm{mm}$ - milimeters. 


\section{RESULTS}

\section{Differentiation in shape}

The canonical analysis of the variables (Fig. 2) indicated differences between the groups. The first canonical variable (CV1) (Fig. 2) was responsible for $74 \%$ of all variation observed in analyzed specimens. This variable was responsible to define the relative length of the valves. Specimens found in extremity of this variable showed a higher or a lower stretching level of the anteroposterior axis. There was made two groups. The first one is represented by Nuculana concentrica and can be totally differentiated from $N$. larranagai and $N$. acuta, because $N$. concentrica is represented by specimens with a higher anteroposterior stretching of valves.

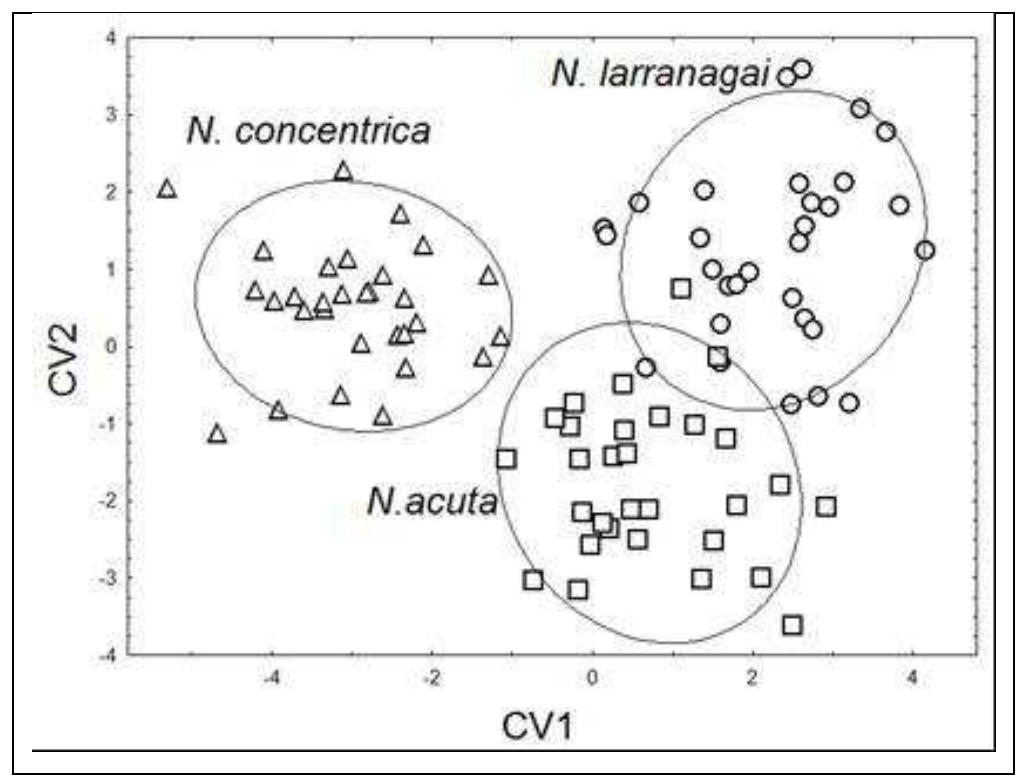

Figure 2 - Canonical Variate Analyses of shape variables of shells of the three species of the genus Nuculana.

The second canonical variable (CV2) contributes with a portion of $25 \%$ from all variation observed among the analyzed specimen, differentiating Nuculana larranagai from $N$. acuta. The specimens from $N$. concentrica are included inside the group associated to the species $N$. larranagai and $N$. acuta. In a particular way there are two well defined clusters only the $N$. larranagai and $N$. acuta. These two are clearly separated in CV2 axis. The valves of $N$. larranagai grouped in the positive way of CV2 are characterized by the expansion of the ventral margin. The valves of $N$. acuta grouped in the negative way of CV2 axis shows a further development of the anteroventral margin.

\section{Differentiation in size and shape}

The variables of size and shape (Fig. 3) were compared and it resulted in three groups. Considering centroid size axis Nuculana acuta can be easily separated for showing the biggest sizes. There is an overlapping of the sizes from $N$. larranagai and $N$. concentrica. In CV1 axis there is a segregation between $N$. larranagai and $N$. concentrica. In this axis all specimens of $N$. acuta overlapped with other species. Size and shape are related, and this relationship can be expressed as follows: the small specimens may be long, $N$. concentric, or short, $N$. larranagai, for anteroposterior axis; Specimens with bigger measurements, $N$. acuta, have a short anteroposterior axis. 


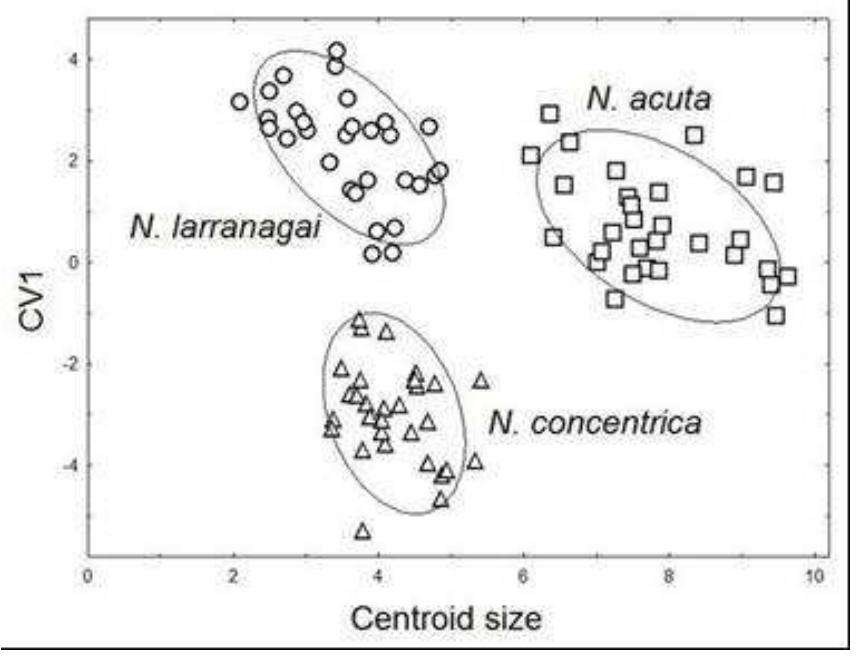

Figure 3 - Comparison between shape (CV1) and size (centroid size scores) of shells of the three species of the genus Nuculana.

\section{DISCUSSION}

Nuculana concentrica is represented by specimens with a higher anteroposterior stretching of valves. This stretching may be due a development of rostral region and escutcheon. This information corroborates the diagnosis registered in literature that mention anteroposterior stretching as an important taxonomic characteristic of this species (SAY, 1925; RIOS, 2009).

Specimens of Nuculana larranagai were characterized for an increase in dorsoventral axis and for an expansion of the ventral margin. This species has a short rostral region and an umbo characterized as sub-central (RIOS, 2009).

Analysis showed that valves of $N$. acuta presented a further development in the postventral margin defined by an increase of rostrum. A long rostrum is a feature well known in literature that defines this species (ALLEN; SANDERS, 1996; RIOS, 2009).

Measures showed in literature disagree about the overlapping between Nuculana larranagai (Lt $\leq 5 \mathrm{~mm}$ ) and $N$. concentrica ( $\mathrm{Lt}=12 \mathrm{~mm}, \mathrm{Wt}=7 \mathrm{~mm}$ ) and suggest that these species may be separated according to its size (RIOS, 2009). N. acuta specimens may be separated by their big dimensions. However, according to Rios (2009) and Allen and Sanders (1996), N. acuta $(\mathrm{Lt}=9 \mathrm{~mm}, \mathrm{Wt}=4.7 \mathrm{~mm})$ have size scores smaller than $N$. concentrica $(\mathrm{Lt}=12 \mathrm{~mm}, \mathrm{Wt}=7 \mathrm{~mm})$.

\section{CONCLUSION}

There are morphological differences that allow a separation of Nuculana acuta (Conrad, 1831), N. concentrica (Say, 1824) and N. larranagai Klappenbach \& Scarabino, 1968], from analyzed species, considering the shape and size of the valves.

\section{ACKNOWLEDGMENTS}

To Dr. Diego Astúa (Departamento Zoologia, UFPE), Mr. Hermon Augusto Jr. and Henrique Rangel (Instituto Oceanário de Pernambuco) whose critics and suggestions improved the manuscript; CNPq (Conselho Nacional de Ciência e Tecnologia) for the financing granted to the study.

\section{REFERENCES}

ABSALÃO, R. S.; ROBERG, R. A. P. Complexo Littorina ziczac (Gmelin) (Mollusca, Gastropoda, Caenogastropoda) no litoral fluminense: analise morfométrica, distribuição e bioquímica. Revista Brasileira de Zoologia. v. 16, n, 2 p. 381-395, 1999. 
ALLEN, A.; SANDERS H. L. Studies on the deep sea Protobranchia (Bivalvia): The family Neilonellidae and subfamily Nuculaninae. Bulletin of the British Museum Natural History. Zoology. v. 62, p. 101-132, 1996.

ALLEN, J. A.; HANNAH, F. J. A reclassification of the Recent genera of the subclass Protobranchia. (Mollusca: Bivalvia). Journal of Conchology. v. 32, p. 102-146, 1986.

ASTÚA, D. Evolution of scapula size and shape in Didelphid marsupials (Didephimorphia: Didelphidae). Evolution. v. 63, p. 2438-2456, 2009.

FUIMAN, L. A.; GAGE, J. D.; LAMONT P. A. Shell morphometry of the deep sea protobranch bivalve Ledella pustulosa in the Rockall Trough, North-East Atlantic. Journal of Marine Biological Association United Kingdom. v. 79, p. 661-671, 1999.

MAXWELL, P. A. Comments on "A reclassification of the Recent genera of the subclass Protobranchia. (Mollusca: Bivalvia). by Allen, J.A. \& Hannah, F.J., (1986). Journal of Conchology. v. 33, p. 85-96, 1988.

RIOS, E. C. Compendium of Brazilian Sea Shells. Fundação Cidade do Rio GrandeMuseu Oceanográfico, Rio Grande, 368p, 2009.

ROSENBERG, G. Malacolog 4.1.1: A Database of Western Atlantic Marine Mollusca. [WWW database (version 4.1.1)] Disponivel em http://www.malacolog.org. Acesso em 19 de agosto de 2010.

RUGGIERO, E.; RAIA, P.; BUONO, G. Geometric morphometrics species discrimination within the genus Terebratula from the Late Cenozoic of Italy. Fossil and Strata. v. 54, p. 209-217, 2008.

SAY, T. An account of some fóssil shells of Maryland. Journal Academy natural of Science. v. 4, p. 141, 1925.

ZARDUS, J. D. Protobranch bivalves. Advances in Marine Biology. v. 42, p. 1-65. 2002. 